\title{
Low prevalence of syphilis in Brazilian inmates
}

Authors

Harnoldo Colares

Coelho $^{1}$

Afonso Dinis Costa

Passos

${ }^{1} \mathrm{PhD}$; Professor,

Department of Clinical, Toxicological and

Bromatological Analyses,

Faculty of Pharmaceutical

Sciences of Ribeirão Preto

- USP

${ }^{2}$ Full Professor,

Departament of Social

Medicine, Faculty of

Medicine of Ribeirão Preto USP
Submitted on: 10/7/2010 Approved on: 10/21/2010

Correspondence to: Harnoldo Colares Coelho Via do Café, s/n - Monte Alegre

14040-903 Ribeirão Preto, São Paulo, Brazil

harnoldo@usp.br

We declare no conflict of interest.
The World Health Organization (WHO) estimates that 340 million new cases of curable sexually transmitted diseases (STDs) occurred worldwide in 1999 among adults between the ages of 15 and 49 years. Of these, 937,000 were syphilis cases occurring in Brazil. ${ }^{1}$ According to the Ministry of Justice, the Brazilian penal system had over 490,000 prisoners in June 2010. ${ }^{2}$ Despite this high number, very few studies in our environment address the prisoner population, especially syphilis infection. The aim of this study was to estimate the prevalence of Treponema pallidum infection and its risk factors among the inmates at the Ribeirão Preto Penitentiary, located in this city, São Paulo State, Southeast Brazil.

Between May and August 2003, 333 participants were interviewed out of a total of 893 prisoners, using a sample design described elsewhere. ${ }^{3}$ All subjects who agreed to participate were included in the study and provided a signed consent after being informed about the objectives and methodology of the study. The Venereal Disease Research Laboratory (VDRL - Laborclin RPR Bras) test was administered to screen for syphilis. Positive samples had their results confirmed by Fluorescent Treponemal Antibody Absorption (FTA-Abs), through the Imuno-Con FTA-ABS (Wama Diagnóstica) test. Both tests were processed and interpreted according to the manufacturer's specifications. Test results were disclosed to each participant individually. Those with positive results for syphilis received specific treatment. Association between variables were assessed by the Fisher's Exact Test. This study was approved by the Ethics Committee of the Hospital das Clínicas at Faculdade de Medicina de Ribeirão Preto at Universidade de São Paulo (USP), process HCRP number 10166/2002.
The participants' ages ranged between 19 and 69 years, with an average of 30.1 years, and a median of 28 years. Ten out the 333 study participants turned out VDRL positive, eight with titers ranging from 1:1 to 1:4, and two a titer of 1:8. All ten VDRL positive participants were also FTA-Abs positive, suggesting a total prevalence of $3.0 \%\left(\mathrm{CI}_{95 \%}: 1.2-4.8\right)$. According to the interviews none of the positive individuals reported any complaints or presented a clinical condition suggestive of syphilis.

The distribution of the participants according to the presence of certain risk factors for syphilis revealed a predominance of individuals with total imprisonment sentence for less than five years $(4.3 \%)$ and had completed only part of their time in prison (less than five years) $(3.3 \%)$. Furthermore, most participants did not have a previous STD history and were heterosexuals and admitted having unprotected sex. Only one syphilis positive individual was HIV-infected (5.3\%). None of these variables were associated with syphilis positive serology.

In Brazil, studies addressing the occurrence of syphilis in prisons are rare and have usually reported higher prevalence than that found in the overall community of Ribeirão Preto. One study conducted in the early 1990 s reported a prevalence rate of $18.1 \%$ in the Carandiru complex, in São Paulo city. ${ }^{4}$ In the late 1990s, a study by Soares et al. reported a $7.4 \%$ rate for the State of Minas Gerais. ${ }^{5}$

The screening strategy using VDRL test may have played a role in the finding of this relatively low prevalence among the Ribeirão Preto prisoners, since a negative VDRL does not rule out previous syphilis infection, as successfully treated patients will likely have a negative VDRL. Another possible factor is the educational work for STD prevention that took place at the penitentiary. It is worth mentioning that most Brazilian studies regarding STDs 
in prisons were conducted in the 1990s or earlier, when there were no continuous preventive measures for these diseases in the prison system. The low number of positive cases may have contributed to the lack of power to demonstrate any association with syphilis infection and the studied risk factors. including the presence of ulcerative STDs and homosexual behavior. However, the high number of individuals who admitted having unsafe sex underscores the need for permanent activities aimed at preventing STDs among the encacerated population.

[Braz J Infect Dis 2011;15(1):94-95] @Elsevier Editora Ltda.

\section{REFERENCES}

1. World Health Organization Department of HIV/AIDS. Global prevalence and incidence of selected curable sexually transmitted infections 2001;Nov:1-50.

2. Brasil. Ministério da Justiça. Secretaria Nacional de Justiça. Departamento Penitenciário Nacional. Sistema Integrado de Informações Penitenciárias - InfoPen 2010. Available at: http://portal.mj.gov.br/data/Pages/MJD574E9CEITEMIDC37B2AE94C6840068B1624D28407509CPTBRIE.htm

3. Coelho HC, Perdoná GC, Neves FR, Passos AD. HIV prevalence and risk factors in a Brazilian penitentiary. Cad Saúde Pública 2007; 23:2197-204.

4. Massad E, Rozman M, Azevedo RS, Silveira AS, Takey K, Yamamoto Y I et al. Seroprevalence of HIV, HCV and syphilis in Brazilian prisoners: Preponderance of parenteral transmission. Eur J Epidemiol. 1999; 15:439-45.

5. Catalan-Soares B, Almeida R, Proietti A. Prevalence of HIV1/2, HTLV-I/II, hepatitis B virus (HBV), hepatitis C virus (HCV), Treponema pallidum and Trypanosoma cruzi among prison inmates at Manhuaçu, Minas Gerais State, Brazil. Rev Soc Bras Med Trop. 2000; 33:27-30. 